\title{
THE COURSE OF CHRONIC ACTIVE HEPATITIS
}

\author{
Yvonne Arthurs, G. D. Doyle and J. F. Fielding* \\ Departments of Medicine and Gastroenterology and Pathology, The \\ Charitable Infirmary, Jervis Street, Dublin 1.
}

\section{Summary}

THIRTY-one patients with histologically diagnosed chronic active hepatitis were followed clinically, biochemically and histologically for a mean of 32.5 months. Nineteen patients were intravenous drug abusers. Eighteen patients showed histological improvement: of these 14 had hepatitis B virus (HBV) associated disease. Thirteen patients were unchanged or worse on repeat biopsy; 5 of these had HBV associated disease. The results of this study suggest that HBV associated chronic active hepatitis is a less severe disease with a better prognosis than non HBV disease.

\section{Introduction}

Chronic active hepatitis was traditionally believed to be a disease with a poor prognosis, and if untreated a life expectancy of about 5 years (MacKay and Wood, 1962; Bearn, Knuckel and Slater, 1956). Subsequent work proved this to be untrue of hepatitis B virus (HBV) associated chronic active hepatitis which was found to have a better prognosis (Sherlock, 1974). In this study, we report the clinical, biochemical and histological prognosis in 31 patients with chronic active hepatitis followed for between 6 and 84 months.

\section{Patients and Methods}

Patients were selected for inclusion in this study on the basis of a histological diagnosis of chronic active hepatitis and having had at least one biopsy 6 or more months following the initial biopsy. There were 19 drug abusing patients who were referred from the Drug Advisory and Treatment Centre, and 12 non drug abusing patients who were attending the Department of Medicine and Gastroenterology.

Each patient was examined for stigmata of chronic liver disease and in drug abusing patients stigmata of such abuse was sought.

Each patient had blood taken for estimation of haemoglobin, white cell count, platelet count, prothrombin time, serum aspartate, transaminase (SGPT) alkaline phosphatase, bilirubin, total serum proteins, serum albumin, immunoglobulins, IgG, IgA, IgM, anti-nuclear factor, anti-mitochondrial antibody and smooth muscle antibody. The presence of hepatitis B surface antigen $\left(\mathrm{HB}_{\mathrm{s}} \mathrm{Ag}\right)$ and antibody $\left(\right.$ anti $\mathrm{HB}_{\mathrm{s}}$ was sought.

Liver biopsy was performed following informed consent. Histological diagnosis was made according to the criteria suggested in a Review by an International Group (1977) in which the classification of DeGroote and his colleagues (1968) was modified and extended. Chronic active hepatitis was therefore defined as "a chronic inflammatory and fibrosing lesion of the liver, of varied aetiology and varied histological features. The features common to all untreated examples are: piecemeal necrosis together with new fibre formation and lymphocyte infiltration of the portal tracts and lobules. Other infiltrating cells may be found and features of acute hepatitis may be superimposed. Passive septae formed after bridging or multilobular liver cell necrosis may be present. Cirrhosis is not a defining criterion, but may develop".

\footnotetext{
* Requests for reprints to Dr. John Fielding, Department of Medicine and Gastroenterology, the Charitable Infirmary, Jervis St., Dublin 1

This article is a reproduction of that published in: Irish Journal of Medical Science, 1982, 151, pp.298-303. Pagination may not match that of the original.
} 
Following diagnosis patients were treated either with prednisolone $10 \mathrm{mg}$ daily and azothiaprine $50 \mathrm{mg}$ daily (Summerskill et al, 1975) or (7 drug abusing patients) sulphasalazine 1g 3 times daily (Fielding, Arthurs and Doyle, 1982).

Patients were reviewed at regular intervals on an out-patient basis and after 6 or more months, one or more repeat liver biopsies were performed. Chronic active hepatitis, chronic persistent hepatitis and cirrhosis were diagnosed according to the criteria of an International Group (1977). Minor changes were said to be present if there was mild swelling of the portal tracts with excess cellular infiltrate with or without foci of hepatocellular necrosis.

\section{Results}

Thirty-one patients were studied, 22 male and 9 female whose ages ranged from 12 to 60 (mean 30.5) years. The duration of follow-up was 6 to 84 (mean 32.5) months. Nineteen patients were known intravenous drug abusers. Eight patients had a past history of jaundice between 6 months and 20 years before diagnosis. Twenty-one patients presented initially with jaundice. One had recurrent episodes of jaundice and 2 were never jaundiced.

On examination 16 patients had stigmata of chronic liver disease. Ten patients had hepatomegaly, one also had splenomegaly. Six patients had palmar erythema, 5 had spider naevi, and one had Dupuytren's contractures. Eighteen drug abusing patients had markings compatible with intravenous abuse.

Nineteen patients were $\mathrm{HB}_{\mathrm{s}} \mathrm{Ag}$ positive and 12 were $\mathrm{HB}_{\mathrm{s}} \mathrm{Ag}$ and anti $\mathrm{HB}_{\mathrm{s}}$ negative (Table I). Transaminase levels were normal in only 2 patients at diagnosis and at the end of 12 months in 8 of 25 patients followed for at least one year. In 4 of the 6 patients followed for 6 months levels had returned to normal at the end of this time (Tables II and III). Ten patients had elevated immunoglobulins (Table IV). Total serum proteins were elevated above $80 \mathrm{~g} / 1$ in 5 patients.

TABLE I

\begin{tabular}{lcc}
\hline Patient group & $\mathrm{HB}_{\mathrm{s}} \mathrm{Ag}$ Positive & $\begin{array}{c}\mathrm{HB}_{\mathrm{s}} \mathrm{Ag} \text { and anti } \\
\mathrm{HB}_{\mathrm{s}} \text { negative }\end{array}$ \\
\hline $\begin{array}{c}\text { Drug abusers } \\
(9)\end{array}$ & 15 & 4 \\
$\begin{array}{c}\text { Non abusers } \\
(12)\end{array}$ & 4 & 8 \\
\hline TOTAL & 19 & 12 \\
\hline
\end{tabular}

$\mathrm{HB}_{\mathrm{s}} \mathrm{Ag}$ and anti $\mathrm{HB}_{\mathrm{s}}$ status in patients with $\mathrm{CAH}$.

A total of 92 liver biopsies were carried out in these patients. Two patients had 6 biopsies, 2 and 5, 3 hand 4, 10 had 3 and 14 had 2 biopsies. The histological

This article is a reproduction of that published in: Irish Journal of Medical Science, 1982, 151, pp.298-303. Pagination may not match that of the original. 
TABLE II

\begin{tabular}{rrc}
\hline \multicolumn{1}{l}{$\begin{array}{l}\text { SGPT level } \\
\text { IU/I } \\
(\mathrm{N}=<45)\end{array}$} & Diagnosis & Twelvemonths \\
\hline $\begin{array}{r}<45 \\
45-99\end{array}$ & 2 & 8 \\
\hline $100-299$ & 7 & 14 \\
\hline $300-499$ & 4 & 2 \\
\hline $500-999$ & 3 & \\
\hline $1000-3000$ & 7 & \\
\hline
\end{tabular}

SGPT levels at diagnosis and 12 months in 25 patients followed for over a year.

TABLE III

\begin{tabular}{rrc}
\hline \multicolumn{1}{l}{$\begin{array}{l}\text { SGPT level } \\
\text { IU/I } \\
(\mathrm{N}=<45)\end{array}$} & Diagnosis & Six months \\
\hline & & 4 \\
\hline$<5-99$ & & 2 \\
\hline $100-299$ & 1 & \\
\hline $300-499$ & 1 & \\
\hline $500-999$ & 4 & \\
\hline $1000-3000$ & & \\
\hline
\end{tabular}

SGPT levels in 6 patients followed for 6 months.

TABLE IV

\begin{tabular}{ccccc}
\hline Patient group & $\begin{array}{c}\text { No. with abnormal } \\
\text { immunoglobulins }\end{array}$ & $\begin{array}{c}\text { IgG } \\
\mathrm{N}=90-200 \mathrm{IU} / \mathrm{ml}\end{array}$ & $\begin{array}{c}\text { IgM } \\
(55-285 \mathrm{IU} / \mathrm{ml})\end{array}$ & $\begin{array}{c}\text { IgA } \\
(40-315 \mathrm{IU} / \mathrm{ml})\end{array}$ \\
\hline $\begin{array}{c}\text { Drug abusers } \\
(19)\end{array}$ & 3 & 1 & 3 & 1 \\
$\begin{array}{c}\text { Non abusers } \\
(12)\end{array}$ & 7 & 4 & 3 & 3 \\
\hline
\end{tabular}

Abnormal immunoglobulins in drug abusers and non abusers.

progression is tabulated separately for the HBV positive and HBV negative patients in Tables $\mathrm{V}$ and VI.

Two patients developed jaundice during the course of follow-up and 2 patients developed Cushingoid facies; otherwise patients remained clinically well.

\section{Discussion}

The evolution of chronic active hepatitis in 31 patients was studied. Nineteen patients had HBV associated disease (Table I). It is possible that the drug abusing patients who were $\mathrm{HB}_{\mathrm{s}} \mathrm{Ag}$ negative may have had chronic liver disease associated with non $\mathrm{A}$ and non $\mathrm{B}$ viruses as these viruses have been implicated as causal agents in chronic liver disease in parenteral drug abusers (Rakela and Redeker, 1979).

This article is a reproduction of that published in: Irish Journal of Medical Science, 1982, 151, pp.298-303. Pagination may not match that of the original. 
The non abusing patients without evidence of HBV disease were predominantly female, had a higher frequency of abnormality of serum proteins; immunoglobulins, antinuclear factor and smooth muscle antibody were detected more frequently than in the drug abusing group. This would suggest that their disease was of the lupoid variety (Doniach et at, 1966).

Of the total group of patients 18 showed an overall histological improvement, 14 of these had HBV associated disease. Of the 13 patients who were unchanged or had deteriorated on repeat biopsy 5 had HBV associated disease.

Traditionally chronic active hepatitis was believed to have a poor prognosis with life expectancy of less than 5 years following diagnosis (Mackay and Wood, 1962; Bearn, Knukel and Slater, 1956), although these early reports would appear to be related to chronic active hepatitis of severe degree only.

Chronic active hepatitis associated with HBV is believed to have a better prognosis than the lupoid variety in which cirrhosis develops rapidly (Sherlock, 1974). The introduction of specific therapy has greatly altered the prognosis. The beneficial effects of steroids in chronic active hepatitis has been shown by numerous clinical trials (Cook et al, 1971, Soloway et al, 1972; Murray-Lyon et al, 1973; Summerskill et al, 1975). The majority of studies comparing the natural history of chronic active hepatitis with and without HBV appear to have been related to response to treatment. In 1976 Schalm and his colleagues compared the response of severe chronic active hepatitis with and without $\mathrm{HB}_{\mathrm{s}} \mathrm{Ag}$ to prednisolone and found that $\mathrm{HB}_{\mathrm{s}} \mathrm{Ag}$ related disease responded less well.

In their study of 74 patients followed for a median period of 45 months Dietrickson and Christofferson (1977) concluded that progression is slow and prognosis better in patients with $\mathrm{HB}_{\mathrm{s}} \mathrm{Ag}$ related disease. The findings in this review would support that claim.

A long-term follow-up study of chronic active hepatitis was published in 1978 by DeGroote et al. Thirty-five patients, 
TABLE V

Histological evolution in $19 \mathrm{HBV}$ positive patients.

\begin{tabular}{|c|c|c|c|c|c|}
\hline First biopsy & Second biopsy & Third biopsy & Fourth biopsy & Fifth biopsy & Sixth biopsy \\
\hline$\overline{\mathrm{CAH}}$ & Minor changes & Minor changes & & & \\
\hline $\mathrm{CAH}$ & $\begin{array}{l}\text { Increased cellular } \\
\text { activity and } \\
\text { necrosis }\end{array}$ & $\begin{array}{l}\text { CAH with early } \\
\text { cirrhosis }\end{array}$ & & & \\
\hline $\begin{array}{l}\text { CAH with early } \\
\text { cirrhosis }\end{array}$ & $\begin{array}{l}\text { Less activity } \\
\text { Less fibrosis }\end{array}$ & Minor changes & Minor changes & & \\
\hline $\mathrm{CAH}$ & $\begin{array}{l}\text { CAH with less } \\
\text { infiltrate } \\
\text { Less necrosis }\end{array}$ & & & & \\
\hline $\mathrm{CAH}$ & Less activity & $\mathrm{CPH}$ & & & \\
\hline $\mathrm{CAH}$ & $\begin{array}{l}\text { CAH with } \\
\text { virrhosis } \\
\text { Less activity }\end{array}$ & & & & \\
\hline $\mathrm{CAH}$ & Less activity & & & & \\
\hline $\mathrm{CAH}$ & $\begin{array}{l}\text { CAH more } \\
\text { fibrosis }\end{array}$ & CAH less activity & & & \\
\hline $\mathrm{CAH}$ & $\begin{array}{l}\text { CAH less } \\
\text { activity }\end{array}$ & & & & \\
\hline $\mathrm{CAH}$ & $\begin{array}{l}\text { CAH less } \\
\text { activity }\end{array}$ & & & & \\
\hline $\mathrm{CAH}$ & CAH less activity & & & & \\
\hline $\begin{array}{l}\text { CAH with early } \\
\text { cirrhosis }\end{array}$ & Improved & & & & \\
\hline $\mathrm{CAH}$ & $\begin{array}{l}\text { CAH less } \\
\text { activity }\end{array}$ & & & & \\
\hline $\begin{array}{l}\text { CAH with } \\
\text { cirrhosis }\end{array}$ & $\begin{array}{l}\text { CAH with } \\
\text { cirrhosis but } \\
\text { less hepatocellular } \\
\text { necrosis }\end{array}$ & Unchanged & & & \\
\hline $\begin{array}{l}\text { CAH with } \\
\text { Cirrhosis }\end{array}$ & $\begin{array}{l}\text { Increased } \\
\text { Cellular } \\
\text { infiltrate and } \\
\text { increased } \\
\text { necrosis }\end{array}$ & Unchanged & $\begin{array}{l}\text { Further } \\
\text { Progression } \\
\text { in severity }\end{array}$ & Unchanged & $\begin{array}{l}\text { No } \\
\text { improvement }\end{array}$ \\
\hline $\begin{array}{l}\text { CAH with early } \\
\text { cirrhosis }\end{array}$ & $\begin{array}{l}\text { Increased } \\
\text { fibrosis }\end{array}$ & $\begin{array}{l}\text { CAH with } \\
\text { Established } \\
\text { cirrhosis }\end{array}$ & Unchanged & & \\
\hline $\begin{array}{l}\text { CAH with } \\
\text { cirrhosis }\end{array}$ & $\begin{array}{l}\text { Persistance of } \\
\text { Hepatocellular } \\
\text { necrosis }\end{array}$ & $\begin{array}{l}\text { CAH with } \\
\text { cirrhosis and } \\
\text { fatty } \\
\text { infiltration }\end{array}$ & & & \\
\hline CAH & $\begin{array}{l}\text { CAH less } \\
\text { activity }\end{array}$ & & & & \\
\hline $\mathrm{CAH}$ & $\begin{array}{l}\text { CAH less } \\
\text { activity }\end{array}$ & & & & \\
\hline
\end{tabular}

This article is a reproduction of that published in: Irish Journal of Medical Science, 1982, 151, pp.298-303. Pagination may not match that of the original. 
TABLE VI

Histological evolution in $12 \mathrm{HBV}$ negative patients.

\begin{tabular}{|c|c|c|c|c|c|}
\hline First biopsy & Second biopsy & Third biopsy & Fourth biopsy & Fifth biopsy & Sixth biopsy \\
\hline $\begin{array}{l}\text { CAH with early } \\
\text { cirrhosis }\end{array}$ & $\begin{array}{l}\text { Increased } \\
\text { cellular } \\
\text { infiltrate and } \\
\text { fibrosis }\end{array}$ & $\begin{array}{l}\text { CAH with } \\
\text { cirrhosis and } \\
\text { fatty infiltrate }\end{array}$ & Unchanged & & \\
\hline $\mathrm{CAH}$ & $\begin{array}{l}\text { CAH less fibrosis } \\
\text { Reduced } \\
\text { Cellularity }\end{array}$ & & & & \\
\hline $\begin{array}{l}\text { CAH with } \\
\text { cirrhosis }\end{array}$ & $\begin{array}{l}\text { CAH with } \\
\text { cirrhosis }\end{array}$ & $\begin{array}{l}\text { Decreased } \\
\text { fibrosis but } \\
\text { persistent } \\
\text { hepatocellular } \\
\text { necrosis }\end{array}$ & $\begin{array}{l}\text { Improved } \\
\text { minor changes }\end{array}$ & Minor changes & \\
\hline CAH & $\begin{array}{l}\text { CAH with } \\
\text { cirrhosis }\end{array}$ & Unchanged & & & \\
\hline $\begin{array}{l}\text { CAH with early } \\
\text { cirrhosis }\end{array}$ & $\begin{array}{l}\text { CAH with } \\
\text { established } \\
\text { cirrhosis }\end{array}$ & Unchanged & Unchanged & $\begin{array}{l}\text { Reduced } \\
\text { cellularity } \\
\text { and fibrosis }\end{array}$ & $\begin{array}{l}\text { Improvement } \\
\text { maintained }\end{array}$ \\
\hline $\begin{array}{l}\text { CAH with early } \\
\text { cirrhosis }\end{array}$ & $\begin{array}{l}\text { Less necrosis } \\
\text { Less cellular } \\
\text { infiltrate }\end{array}$ & Unchanged & $\begin{array}{l}\text { Further } \\
\text { reduction } \\
\text { in activity }\end{array}$ & $\begin{array}{l}\text { Less cellular } \\
\text { infiltrate } \\
\text { Less fibrosis }\end{array}$ & \\
\hline $\begin{array}{l}\text { CAH with } \\
\text { cirrhosis }\end{array}$ & Unchanged & & & & \\
\hline $\begin{array}{l}\text { CAH with early } \\
\text { cirrhosis and } \\
\text { fatty infiltration }\end{array}$ & Unchanged & & & & \\
\hline $\begin{array}{l}\text { CAH with early } \\
\text { cirrhosis }\end{array}$ & Unchanged & & & & \\
\hline $\mathrm{CAH}$ & $\mathrm{CAH}$ & & & & \\
\hline $\begin{array}{l}\text { CAH with early } \\
\text { cirrhosis }\end{array}$ & Unchanged & $\begin{array}{l}\text { Increased } \\
\text { cellular infiltrate } \\
\text { More } \\
\text { hepatocellular } \\
\text { necrosis }\end{array}$ & & & \\
\hline $\mathrm{CAH}$ & $\begin{array}{l}\text { CAH with early } \\
\text { cirrhosis }\end{array}$ & & & & \\
\hline
\end{tabular}

17 of whom were $\mathrm{HB}_{\mathrm{s}} \mathrm{Ag}$ positive, were followed for up to 15 years (mean 87 months). All patients except one were treated with prednisolone and/or azothiaprine. After stopping therapy 13 patients relapsed; the majority of relapses were seen in $\mathrm{HB}_{\mathrm{s}} \mathrm{Ag}$ positive patients. Two-thirds of $\mathrm{HB}_{\mathrm{s}} \mathrm{Ag}$ positive patients developed cirrhosis between the second and fifth year of evolution compared with less than one-third of the $\mathrm{HB}_{\mathrm{s}} \mathrm{Ag}$ negative group. Although the patients involved in that study of DeGroote and his colleagues (1978) compare closely with those in this review, the results do not. Our $\mathrm{HB}_{\mathrm{s}} \mathrm{Ag}$ positive patients had a histologically less severe disease with less cirrhosis than the $\mathrm{HB}_{\mathrm{s}} \mathrm{Ag}$ negative group.

The majority of drug abusing patients in our study who were treated with prednisolone and azothiaprine did not comply with therapy. Paradoxically this may have had a beneficial effect on the course of their disease, as a recent report suggests that prednisolone used to treat $\mathrm{HB}_{\mathrm{s}} \mathrm{Ag}$ associated chronic active hepatitis may have a deleterious effect on the course of the disease (Lam et at, 1981).

Koretz et at (1980) pointed out that the most severe chronic active hepatitis is not associated with HBV and that the majority of patients seen by them had a less severe illness 
which was HBV related. Nevertheless the incidence of cirrhosis among those patients was $43 \%$, comparable to the $45 \%$ initially reported in severely ill patients (Cook et al, 1971).

The results of this study would support the concept of HBV associated chronic active hepatitis being a less severe disease than non HBV associated chronic active hepatitis; with slower progression and a better prognosis.

\section{References}

Bearn, A. G., Knukel, H. G., Slater, R. J. 1956. The problem of chronic liver disease in young women. Am. J. Med. 21, 3-15.

Cook, G. C., Mulligan, R., Sherlock, S. 1971. Controlled trial of corticosteroid therapy in chronic active hepatitis. Quart. J. Med. 40, 159-185.

DeGroote, J., Desmet, V. J., Gedigk, P., Korb, G., Popper, H., Poulsen, H., Scheuer, P.J., Schmidt, M., Thaler, H., Uehlinger, E. and Wepler, W. 1968. A classification of chronic hepatitis. Lancet ii, 626-628.

DeGroote, J., Favery, J., Lepoutre, L. 1978. Long-term follow-up of chronic active hepatitis of moderate severity. Gut 19, 510-513.

Detrickson, O. and Christofferson, P. 1977. The prognosis of chronic aggressive hepatitis. A clinical and morphological follow-up study. Scand J. Gastroent. 12, 289-295.

Doniach, D., Roith, I. M., Walker, J. G., Sherlock, S. 1966. Tissue antibodies in primary biliary cirrhosis, active chronic (lupoid) hepatitis, cryptogenic cirrhosis and their clinical implications. Clin. Exp. Immunol. 1, 237-282.

Fielding, J. F., Arthurs, Y., Doyle, G. D. 1982. A pilot study of sulphasalazine treatment in hepatitis B virus (HBV) associated chronic active hepatitis. Irish Med. J. 75, 91-92.

Koretz, R. L., Lewin, K. J., Higgins, J., Fagen, M. D., Gitnick, G. L. 1980. Chronic active hepatitis. Who meets treatment criteria? Digest Dis. and Sci. 25, 9, 695-699.

Lam, K. G., Lai, C. L, Trepo, C., Wu, P. C. 1981. Deleterious effect of prednisolone in $\mathrm{HB}_{\mathrm{s}} \mathrm{Ag}$ positive chronic active hepatitis. N. Eng. J. Med. Vol. 304, No. 7, 380-386.

MacKay, I. R., Wood, I. J. 1962. Lupoid hepatitis. A comparison of 22 cases with other types of chronic liver disease. Quart. J. Med. N.S. 31, 485-507.

Murray-Lyon, I. M., Stern, R. B., Williams, R. 1973. Controlled trial of prednisolone and azothiaprine in active chronic hepatitis. Lancet i, 735-737.

Rakler, J., Redeker, A. G. 1979. Chronic liver disease after acute non A non B viral hepatitis. Gastroenterology 77, 1200-1202.

Review by an International Group. 1977. Acute and chronic hepatitis revisited. Lancet ii, 914919.

Schalm, S. W., Summerskill, W. H. J., Gitnick, G. L., Elveback, L. R. 1976. Contrasting features and response to treatment of severe chronic active liver disease with and without hepatitis $\mathrm{B}_{\mathrm{s}}$ antigen. Gut 17, 781-785.

Sherlock, Sheila. 1974. Progress Report. Chronic Hepatitis. Gut 15, 581-597.

Soloway, R. D., Summerskill, W. H. J., Baggenstoss, A. H., Geall, M. G., Gitnick, G. L., Elveback, L. R. and Schoenfield, L. J. 1972. Clinical, biochemical and histological remission of severe chronic active liver disease. A controlled study of treatment and early prognosis. Gastroenterol 63, 5, 820-833.

Summerskill, W. H. J., Korman, M. G., Ammon, H. V., Baggenstoss, A. H. 1975. Prednisolone for chronic active liver disease : dose titration, standard dose and combination with azothiaprine compared. Gut 16, 876-883.

This article is a reproduction of that published in: Irish Journal of Medical Science, 1982, 151, pp.298-303.

Pagination may not match that of the original. 